\title{
Lelang Jabatan dalam Sistem Hukum di Indonesia
}

\section{Elidar Sari1}

Dosen Fakultas Hukum Universitas Malikussaleh

Ketua Gugus Jaminan Mutu Fakultas Hukum Universitas Malikussaleh

elidar.sari@yahoo.com

\begin{abstract}
The case of official positional auction under Indonesia legal system is not yet determined hence on this case, the civil servant regulation is adopted as a reference on goverment organization. Therefore, the government body or state officials may consider any policy in order to fullfil the public demand. Indonesian officials have right to act based on Fress Ermessen's principle which can provides the freedom for authorized party to make decision as long as it is still on the track and does not overreach legal procedure. Consequently, the official positional auction is considered as a policy that belong to all state officials as long as it does not againts the law.
\end{abstract}

\section{Keywords:}

Positional official auction, indonesian legal system

\begin{abstract}
Abstrak
Lelang jabatan dalam sistem hukum Indonesia belum ada pengaturannya, sehingga dalam pelaksanaannya masih memakai ketentuan yang ada dalam Undang-Undang Kepegawaian sebagai acuan dasar penyelenggaraan pemerintahan, sehingga badan atau pejabat negara dalam menentukan kebijakan apa yang dapat diambil asal itu dilakukan atas dasar kepentingan umum dan sesuai dengan harapan dan kebutuhan masyarakat. pejabat di Indonesia diberi hak untuk memegang asas Fress Ermessen, dimana ada kebebasan bagi penguasa untuk bertindak selama tidak menyalahi aturan dan tidak melampaui batas kewenangan serta tidak menyalahgunakan kewenangan. Jadi, lelang jabatan adalah suatu kebijakan dan kebijakan adalah hak semua pejabat untuk melakukannya selama tidak menyalahi aturan hukum yang ada.
\end{abstract}

\section{Kata Kunci:}

Lelang Jabatan, Sistem Hukum Indonesia 


\section{A. PENDAHUluan}

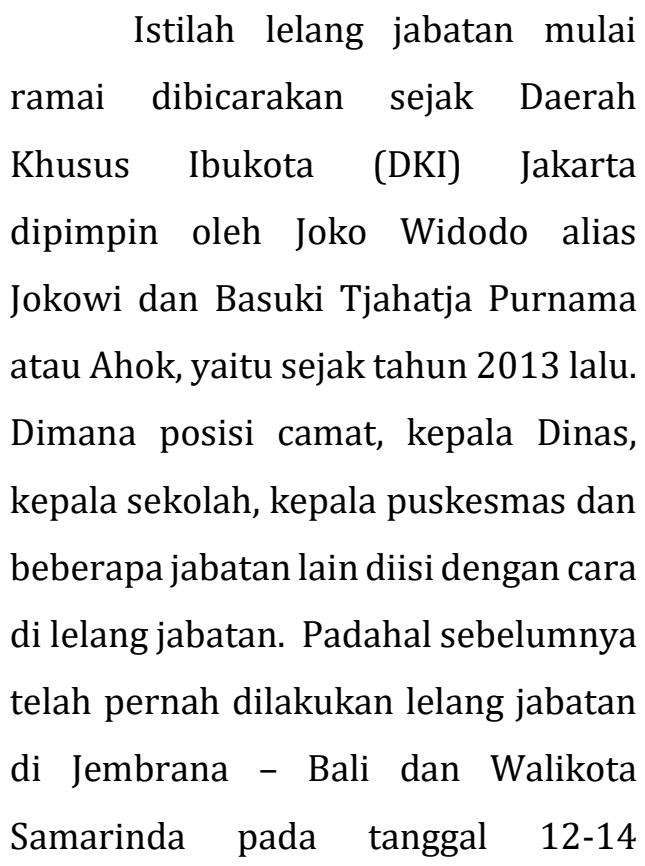

Februari 2013. Jokowi-Ahok baru melaksanakannya pada tanggal 8-22 April 2013, dan langsung menjadi sorotan publik.

$\begin{array}{ccc} & \text { Lelang dalam kamus hukum } \\ \text { yang diterbitkan citra umbara }\end{array}$
Bandung menyebutkan bahwa setiap penjualan barang di muka umum dengan cara penawaran harga secara lisan dan atau tertulis melalui usaha pengumpulan peminat atau calon pembeli. Sedangkan Jabatan dalam kamus hukum mempunyai banyak kategori. Ada jabatan saja, jabatan fungsional, jabatan karier, jabatan negeri, jabatan organik dan jabatan struktural. Untuk istilah jabatan adalah kedudukan yang menunjukkan tugas, tanggung jawab, wewenang, dan hak seseorang pegawai negeri sipil dalam suatu satuan organisasi negara. ${ }^{1}$

Ada baiknya diketahui juga apa itu makna dari istilah jabatan lainnya, seperti jabatan fungsional adalah jabatan yang tidak secara tegas disebutkan dalam struktur organisasi, tetapi sudut fungsinya diperlukan oleh organisasi, seperti peneliti, dokter, pustakawan dan lain-lain yang serupa dengan itu. Jabatan negeri adalah jabatan dalam bidang eksekutif yang ditetapkan berdasarkan peraturan perundang-undangan termasuk didalamnya jabatan dalam kesekretariatan lembaga tertinggi/ tinggi negara dan kepaniteraan pengadilan. Jabatan organik adalah jabatan negeri yang menjadi tugas pokok pada suatu satuan organisasi pemerintahan. Sedangkan jabatan struktural adalah suatu kedudukan yang menunjukkan tugas, tanggung jawab, wewenang dan hak seorang anggota kepolisian dalam rangka

1 Kamus Hukum, Citra Umbara, Bandung, Cet. Ke-5, 2008, hlm. 169 dan 238. 
memimpin suatu satuan organisasi kepolisian. ${ }^{2}$

Jokowi-Ahok melakukan lima (5) tahap lelang jabatan pada saat akan melakukan seleksi calon, yaitu: tahap pertama seleksi administrasi, tahap kedua seleksi kesehatan, tahap ketiga seleksi pengetahuan, tahap keempat Analisi SWOT (Strengths Weakneses Opportunities Threats) dan tahap terakhir psikologi test dan wawancara. Semua tahapan ini harus dilalui dengan syarat administrasi nya adalah usia maksimal 52 tahun, pangkat minimal III/d, telah ikut pelatihan kepemimpinan atau telah pernah menduduki jabatan fungsional, pendidikan minimal strata satu (sarjana), melampirkan DP3 (prestasi kerja) minimal dua tahun, dan sehat bebas dari narkoba. Perkiraan dana yang dihabiskan pada saat lelang jabatan itu dilakukakan adalah lebih kurang mengeluarkan dana 7 milyar rupiah.

Pemerintahan Daerah Khusus Ibukota (DKI) Jakarta menganggap bahwa itu adalah suatu perbuatan yang bagus untuk struktirisasi pemerintahan dan mecegah terjadinya penyalahgunaan jabatan. Diharapkan usaha ini bisa menjadi suatu upaya memperbaiki birokrasi yang sudah hancur dan bisa meningkatkan pelayanan kepada masyarakat. Dan sudah pasti tindakan ini menimbulkan pro dan kotra, dimana yang paling kontra atau tidak senang dengan lelang jabatan ini adalah partai demokrat yang langsung memberi kritikan yang disampaikan oleh Ahmad Husein Alaydrus dari komisi C Dewan Perwakilan Rakyat Daerah (DPRD) DKI.

Keberhasilan yang diyakini pemerintah mengenai lelang jabatan di DKI Jakarta ini mulai berhembus kepada pemerintah pusat, yaitu kementrian-kementrian. Diawali dengan lelang jabatan eselon $1 \mathrm{di}$ tubuh Kementrian Keuangan Republik Indonesia dengan metode lelang jabatan mulai terhembus kencang, yaitu pengisian jabatan untuk 4 jabatan, yaitu irjen Pajak, Kepala Badan Kebijakan Fiskal, Staf Ahli Bidang Organisasi, Birokrasi dan Teknologi Informasi serta Staf Ahli Bidang Penerimaan Negara. Kabar yang sedang menghangat juga lelang jabatan ini akan melibatkan KPK dan PPATK dalam hal pemeriksaan harta 
kekayaan calon pejabat yang mengikuti lelang jabatan tersebut.Untuk dasar hukum prosedur lelang jabatan, hal ini diatur dalam Undang Undang Nomor 23 Tahun 2014 tentang Pemerintahan Daerah, dimana terdapat ketentuan perihal wewenang kepala daerah untuk menentukan struktur Organisasi Pemerintahan Daerah (OPD) dan pengisian jabatannya. Adapun dalam Undang Undang Nomor 43 Tahun 1999 Tentang Perubahan Atas Undang Undang Nomor 8 Tahun 1974 Tentang Pokok Pokok Kepegawaian juga mengatur tentang persyaratan pengisian jabatan bagi Pegawai Negeri Sipil (PNS), yaitu pada pasal 17 ayat (2) disebutkan bahwa "Pengangkatan Pegawai Negeri Sipil dalam suatu jabatan dilaksanakan. berdasarkan prinsip profesionalisme sesuai dengan kompetensi, prestasi kerja, dan jenjang pangkat yang ditetapkan untuk jabatan itu serta syarat obyektif lainnya tanpa membedakan jenis kelamin, suku, agama, ras atau golongan."

Berkaitan dengan tugas dan fungsi dari pegawai negeri, beberapa

pakar memberikan batasan sebagai berikut:

1. Pemerintah suatu welfare state diberi tugas menyelenggarakan kepentingan umum, seperti kesehatan, pengajaran, perumahan, pembagian tanah dan sebagainya. $^{3}$

2. Menurut Prajudi Admosudirjo, tugas aparatur Negara di Indonesia terdiri dari:

a. Perencanaan;

b. Pengaturan;

c. Tata pemerintahan;

d. Kepolisian;

e. Penyelesaian perselisihan secara administrative;

f. Tata Usaha Negara;

g. Pembangunan;

h. Penyelenggaraan usaha-usaha Negara. ${ }^{4}$

Melihat beratnya tugas dari pegawai negeri, dalam hal ini dibutuhkan pegawai negeri yang penuh kesetiaan dan ketaatan terhadap Pancasila dan UUD 1945, Negara dan Pemerintah, serta yang bersatu padu, bermental baik, berwibawa, kuat, berdaya guna,

4 Prajudi Atmosudirjo, Pengantar Administrasi Negara, Ghalia Indonesia, Jakarta, 1982, hlm. 25 
berhasil guna, bersih, berkualitas tinggi dan sadar akan tanggungjawabnya sebagai aparatur Negara dan abdi masyarakat. ${ }^{5}$ Maka untuk melihat bagaimana seyogiyanya lelang jabatan dalam sistem hukum di Indonesia dapat dilihat dalam pemaparan dibawah ini.

\section{B. PERMASALAHAN}

Dari urauian singkat di atas, ada beberapa hal yang menarik untuk dikaji dan dibahas lebih lanjut dalam artikel ini, pembahasan ini berguna untuk mecari formulasi yang tepat sasaran dan bisa membantu memperbaiki birokrasi yang salah selama ini, adapun permasalahan yang akan diangkat adalah:

1. Apakah hukum di Indonesia memungkinkan proses lelang jabatan ini dilaksanakan dan tidak melanggar konstitusi?

2. Apa sajakah kelebihan dan kekurangan dari pelaksanaan lelang jabatan?

\section{PEMBAHASAN}

\section{Dasar Hukum Dan Prosedur Lelang Jabatan}

Sepintas dasar hukum diberlakukannya lelang jabatan adalah yang tertulis di akhir latar belakang artikel ini, dan pada intinya lelang jabatan bisa merupakan suatu kebijakan, dimana kebijakan adalah segala sesuatu yang tidak diatur lebih lanjut oleh peraturan perundangundangan, hal ini sesuai dengan pendapat Philipus M. Hadjon dalam bukunya pengantar hukum administrasi negara. Sehingga hal ini bukan merupakan suatu kesalahan jika diberlakukan. Tetapi juga memperhatikan asas efektifitas dan efisiensi dalam pemerintahan, dimana dalam pelaksanaan hukum administrasi negara lebih banyak ditekankan pada pemahaman asas dikarenakan hukum administrasi negara tidak memiliki hukum materiil yang bisa dipertahankan. Masalah lelang jabatan tidak ada pengaturan baik dalam Undang-undang Pemerintahan daerah maupun dalam Undang-undang Pokok-pokok Kepe-

5 Rozali Abdullah, Hukum Kepegawaian, Penerbit CV. Rajawali Jakarta, 1986, hlm. 22. 
gawaian. Sehingga memungkinkan untuk dilakukan kebijakan untuk ini.

Apa itu kebijakan dan siapa yang berhak mengeluarkan kebijakan itu? Dalam aturan Hukum Administrasi Negara, ada tiga tindakan yang dapat dilakukan pemerintah atau aparatur pemerintah, yaitu: 1) membuat peraturan (regeling), 2) perbuatan materiil dan 3) membuat keputusan atau dikenal dengan kebijakan (beschikking). 6 Jadi pada intinya setiap pejabat negara atau aparatur negara mempunyai hak untuk mengeluarkan suatu keputusan atau kebijakan yang merupakan lingkup kerjanya tanpa menyalahi atau melampaui batas kewenangan nya. Dan lelang jabatan yang dilakukan pejabat DKI tersebut adalah salah satu kebijakan yang telah dipilih gubernur dan wakil gubernur DKI Jakarta. Dasar hukum nya seperti yang tertulis di latar belakang.

Salah satu fungsi aparatur negara adalah melaksanakan Hukum Administrasi Negara (HAN) agar roda

${ }^{6}$ Elidar Sari, Hukum Administrasi Negara, Biena Edukasi, Lhokseumawe, 2013, hlm. 30

${ }^{7}$ Philippus M. Hadjon dkk, Pengantar Hukum Administrasi Indonesia, UGM Press, Cet.Ke-5, 1997, Yogyakarta, hlm. 27 pemerintahan berjalan sebagaimana yang diharapkan oleh Hukum Tata Negara (HTN). HTN mempelajari negara dalam keadaan diam dan HAN dalam keadaan bergerak, HAN menurut de la Bassecour Caan, yang menyatakan bahwa: "HAN adalah himpunan peraturan tertentu yang menjadi sebab negara berfungsi (beraksi). Maka peraturan itu mengatur hubungan antar individu atau warga negara dengan pemerintahnya".7 Salah satu fungsi HAN yang dilaksanakan Pejabat atau aparatur negara adalah mengeluarkan kebijakan (Beschiking), Prins, merumuskan beschikking sebagai suatu tindakan hukum sepihak dalam lapangan pemerintahan yang dilakukan oleh alat pemerintahan berdasarkan wewenang yang ada pada alat atau organ. ${ }^{8}$ Lelang jabatan yang dilakukan pejabat DKI Jakarta adalah salah satu kebijakan.

Pada prinsip nya apa yang dilakukan dalam pengambilan keputusan oleh pejabat negara harus berdasarkan pada ketentuan yang

8W. F. Prins, dalam R. Kosim Adisapoetra, Pengantar Ilmu Hukum Administrasi Negara, Pradnya Paramita, Jakarta, 1987, hlm. 38 
tertulis dalam Undang-Undang Dasar (UUD) 1945, dimana dalam Pasal 1 ayat (2) disebutkan bahwa kedaulatan berada di tangan rakyat dan dilaksanakan menurut UUD. Yang selanjutnya dalam Pasal 1 ayat (3) UUD 1945, negara Indonesia adalah negara hukum, dimana semua harus sesuai dengan konsep negara hukum. Ada banyak konsep negara hukum yang ditawarkan dan Indonesia sebagai salah satu negara yang mengenal Hukum Administrasi Negara tentu memakai asas-asas umum yang berlaku dalam HAN. Dimana dalam HAN mengenal asas Frees Ermessen yaitu kebebasan bertindang seorang pejabat negara selama tidak mengganggu kepentingan umum dalam menjalankan administrasi pemerintahan.

Konsep negara hukum yang dipakai di Indonesia masih terjadi perdebatan, apakah memakai konsep negara hukum rechtstaat atau the rule of law. Dimana konsep negara hukum rechtstaat memandang negara adalah subjek hukum, maka jika ia bersalah dapat dituntut di depan pengadilan. ${ }^{9}$

${ }^{9}$ C.S.T. Kancil dan Chistine S.T. Kancil, Perbandingan Hukum Administrasi Negara, Rineka Cipta, Jakarta, 2000, hlm. 25
Sehingga jika ada kesalahan yang dilakukan badan atau pejabat negara, maka bukan orangnya yang dituntut, tetapi jabatan nya $(\mathrm{amb})$. Sedangkan dalam konsep negara hukum the rule of law mengenal istilah the state can do no wrong , dimana negara tidak dapat dituntut, yang dapat dituntut adalah manusianya. Dalam hal ini negara tidak diidentikkan dengan pejabat negara, negara tidak dapat bersalah, yang mungkin hanyalah pejabat negara, dan dialah yang dihukum. ${ }^{10}$ Dari dua pemahaman konsep negara hukum tersebut, Indonesia jelas memakai konsep rechtstaat dimana dalam Hukum Acara Peradilan Tata Usaha Negara (HAPTUN) di Indonesia pejabat dituntut karena jabatannya bukan orangnya, sehingga jika pejabat yang kalah dalam peradilan, maka negara yang akan membayar yang diambil dari kas negara.

Adapun yang dimaksud dengan administrasi pemerintahan ${ }^{11}$ adalah tata laksana dalam pengambilan keputusan dan/atau tindakan oleh badan dan /atau pejabat pemerintahan. Dan yang dimaksud

10Ibid, hlm. 23

11Isi Pasal 1 ayat (1) Undang-undang Republik Indonesia Nomor 30 Tahun 2014 tentang Administrasi Pemerintahan 
dengan Badan dan/atau Pejabat Pemerintahan ${ }^{12}$ adalah unsur yang melaksanakan fungsi pemerintahan, baik di lingkungan pemerintah maupun penyelenggara negara lainnya. Sedangkan fungsi pemerintahan ${ }^{13}$ adalah fungsi dalam melaksanakan Administrasi Pemerintahan yang meliputi fungsi pengaturan, pelayanan, pembangunan, pemberdayaan, dan perlindungan.

Aparatur negara atau yang dikenal dengan badan atau pejabat negara dalam menjalankan atau dalam penyelenggaraan administrasi pemerintahan harus berdasarkan pada asas utama pemerintahan yaitu asas legalitas, asas perlindungan terhadap hak asasi manusia; dan Asas-asas Umum Pemerintahan yang Baik (AUPB). ${ }^{14}$ Sehingga apapun kebijakan yang akan diambil oleh pejabat pemerintahan hanya terikat pada ketentuan-ketentuan yang berlaku dalam UU administrasi pemerintahan tersebut yang pada dasarnya juga apa yang menjadi aturan dasar yang di pelajari dalam HAN. 2014
Untuk masalah lelang jabatan secara kongkrit tidak diatur dalam UU Kepegawaian sebagai acuan dasar penyelenggaraan pemerintahan, sehingga badan atau pejabat negara dalam menentukan kebijakan apa yang dapat diambil asal itu dilakukan atas dasar kepentingan umum dan sesuai dengan harapan dan kebutuhan masyarakat (citizen friendly). Dan sejauh ini keputusan lelang jabatan yang dilakukan badan atau pejabat pemerintahan DKI belum bisa dibuktikan melanggar peraturan perundang-undangan.

Lima tahap pelaksanaan lelang jabatan yang dilakukan DKI masa Jokowi-Ahok sesuai yang telah dijelaskan di latar belakang di atas, dan proses itu lebih singkatnya adalah disebut Proses promosi jabatan dengan tahapan: Pertama; pengumuman secara terbuka kepada instansi lain dalam bentuk surat edaran melalui papan pengumuman, dan/atau media cetak, media elektronik (termasuk media online/internet) sesuai dengan anggaran yang tersedia. Setiap pegawai yang

\footnotetext{
${ }^{13}$ Pasal 1 ayat (2) UU No. 30 Tahun 2014

${ }^{14}$ Pasal 5 UU No. 30 Tahun 2014
} 
telah memenuhi syarat administratif berupa tingkat kepangkatan dan golongan, diperbolehkan mendaftarkan diri untuk mengisi lowongan yang tersedia; Kedua, mekanisme seleksi/ penilaian kompetensi manejerial dan kompetensi bidang (substansi tugas) Penilaian kompetensi manejerial dilakukan dengan menggunakan metodologi psikometri, wawancara kompetensi dan analisa kasus danpresentasi. Sedangkan penilaian kompetensi bidang dilakukan dengan metode tertulis dan wawancara (Standar kompetensi Bidang disusun dan ditetapkan oleh masing-masing instansi sesuai kebutuhan jabatan dan dapat dibantu oleh assessor.

Ketiga, Panitia Seleksi mengumumkan hasil dari setiap tahap seleksi secara terbuka melalui papan pengumuman, dan/atau media cetak, media elektronik (termasuk media online/internet). Harapannya adalah dengan metode baru lelang jabatan tersebut, akan menjadi terobosan baru dalam birokrasi Indonesia yang oleh berbagai kalangan dinilai bermasalah, apalagi jika menggunakan sistem promosi "politik kasta", yaitu penunjukan pejabat untuk menduduki suatu jabatan oleh pejabat yang lebih tinggi yang rawan KKNsehingga nantinya akan tercipta pejabat yang betul-betul kompeten dalam menjalankan jabatannya, bersih dari KKN, berprestasi dalam proses pelayanan masyarakat. Terobasan baru ini tentu sedikit melawan arus lama yang selama ini dilakukan dalam lingkup pemeritahan diberbagai wilayah, tak terkecuali wilayah DKI Jakarta.

\section{Kelebihan dan Kelemahan Pelaksanaan Lelang Jabatan}

Ada beberapa kelebihan dan kelemahan dari pelaksanaan lelang jabatan yang telah dilakukan. Kelebihan itu dapat dilihat dari pengaruh positif dengan adanya sistem lelang jabatan, yaitu:

1. Dengan sistem lelang jabatan, yaitu adanya fit and proper test, maka diharapkan akan menciptakan persaingan positif dalam kinerja, sehingga nantinya akan tercipta pejabat yang berkompeten pada saat mengemban amanah jabatan.

2. Pada saat dilakukan lelang jabatan, maka akan dilihat bagaimana track record kinerja pejabat tersebut. Oleh karena itu pula, pengaruh positif dengan adanya lelang 
jabatan tersebut adalah penempatan pejabat yang bersih dan berkompeten pada saat menduduki suatu jabatan.

3. Menghindari dari pengisian jabatan yang merupakan "pesanan" dari pihak lain yang memiliki kepentingan dalam hal tugas dan wewenang dari jabatan tersebut.

4. Memberikan peluang yang sama bagi Pegawai Negeri Sipil yang ingin berkarier berdasarkan kinerja dan prestasi kerjanya.

5. Diharapkan dapat terjadi persaingan yang sehat dan dapat memacu semangat untuk terus berkarya dengan baik dan berlomba-lomba mencapai prestasi kerja yang sehat.

6. Merupakan bentuk keterbukaan birokrasi kepada masyarakat, sehingga masyarakat akan lebih percaya kepada pemerintahan, sehingga pemerintahan yang

15 Harian Kompas, Tanggal 21 Desember 2013 
berprestasi secara nasional. Politik kasta yang selama ini menggerogoti birokrasi mulai terkikis karena penilaian pemilihan pejabat dilakukan berdasarkan prestasi dan kompetensi yang dimiliki. Tetapi dampak positif ini bisa juga menjadi dampak negatif jika dilihat dari pengalaman dan kebijakan. Memang usia tidak mempengaruhi tingkat kedewasaan seseorang, tetapi terkadang mempengaruhi cara pengambilan kebijakan yang lebih bijak dengan melihat berbagai sudut pandang.Sebenarnya bagaimanapun bentuk penempatan jabatan pasti membuka peluang buruk jika mau dilakukan karena semua sistem yang dibuat manusia pasti ada celah untuk disimpangi. Tetapi semua berpulang pada pelaku kegiatan dan pada niat baik badan atau pejabat pemerintahan.

Selain beberapa kelebihan tersebut, ada dampak negatif yang mungkin akan timbul dari penerapan lelang jabatan ini, dimana:

1. Karena sistem lelang jabatan dilakukan berdasarkan fit and proper test, maka siapa saja bisa menduduki suatu jabatan tanpa melihat usia dan pengalaman, sehingga kadang- kadang karena pengalaman yang kurang akan situasi dan kondisi kerja menyebabkan dia akan bertindak diluar kebiasaan setempat dan bisa saja terjadi benturan dengan beberapa orang dilingkungan kerjanya.

2. Akibat pengalaman yang kurang bisa saja akan terjadi salah dalam pengambilan kebijakan dan sering bersifat kaku akan aturan.

3. Biasanya juga akan terjadi benturan prinsip atau benturan pendapat dan ketidakdekatan secara emosional dengan pimpinan karena jabatan yang dipegang diperoleh bukan atas dasar rekomendasi atasan nya langsung.

Kelemahan yang mingkin terjadi sesuai uraian diatas bisa saja diatasi dengan berbagai cara dan bisa di minimalisir dengan memperhatikan saat wawancara dan bisa meminta pada lembaga lain yang ahli dalam menilai karakter calon yang akan menduduki suatu jabatan tersebut.

Lelang jabatan pada dasarnya merupakan tantangan Bangsa 
Indonesia dalam berdemokrasi memang sesuatu yang berat, bahkan mungkin merupakan bentuk pemerintahan yang paling rumit dan sulit. Banyak ketegangan dan pertentangan, karena demokrasi mensyaratkan kemauan dan ketekunan para penyelenggaranya agar bisa berhasil. Demokrasi memerlukan pengorbanan berbagai pihak karena demokrasi dirancang untuk penyelenggaraan pemerintahan yang bertanggung jawab. Pemerintahan demokratis memerlukan waktu dan proses untuk dapat dirasakan manfaatnya oleh seluruh warga negara, berbeda dengan pemerintahan diktator yang dapat mengambil keputusan dan bertindak secara tepat. Namun demikian pemerintahan yang demokratis sekali mengambil keputusan dan tindakan dipastikan adanya dukungan publik akibat partisipasi politik rakyat yang tinggi dalam pengambilan keputusan politik. Salah satu perwujudan pelaksanaan demokrasi di Indonesia adalah pelaksanaan lelang jabatan dalam struktur pemerintah daerah. ${ }^{16}$

16 Warsito, Pemilihan Kepala Daerah, Dalam Jurnal Dialogue, JIAKP, Vol. 2, No. 3, September 2005, hlm. 914-915

\section{PENUTUP}

\section{Kesimpulan}

Uraian singkat diatas dapat dipahami dan menjadi topik menarik untuk dikaji lebih mendalam, tetapi secara singkat dan sederhana bahasan artikel ini dapat ditarik kesimpulan, diantaranya adalah:

1. Hukum di Indonesia pada dasarnya membuka peluang dan tidak melarang diberlakukannya lelang jabatan ini, dimana semua pejabat di Indonesia diberi hak untuk memegang asas Fress Ermessen, dimana ada kebebasan bagi penguasa untuk bertindak selama tidak menyalahi aturan dan tidak melampaui batas kewenangan (exes de provoir) serta tidak menyalahgunakan kewenangan (Detuernement de provoir). Jadi, lelang jabatan adalah suatu kebijakan dan kebijakan adalah hak semua pejabat untuk melakukannya selama tidak menyalahi aturan hukum yang ada. 
2. Ada beberapa kelebihan dan kelemahan pelaksanaan lelang jabatan, diantaranya adalah masalah fit and proper test, yang bisa menjadi ajang memilih yang terbaik diantara yang baik. Memang semua itu tentu ada pro dan kontra. Tetapi disadari sekali bahwa setiap kebijakan pasti akan ada pro dan kontra. Lebih jelas kelebihan dan kekurangannya telah di uraikan pada bab di atas.

\section{Saran}

Masalah lelang jabatan ini pada intinya bisa dilakukan dan tidak melanggar aturan hukum yang ada selama itu untuk kepentingan umum dan tidak ada yang dirugikan dalam hal ini. Tetapi butuh penanganan yang serius dan berusaha memperkecil setiap penyimpangan yang mungkin ada atau timbul di lapangan. Setiap kemungkinan yang akan timbul itu akan dapat dikurangi dengan cara membuat aturan yang jelas dan prosedur pelaksanaan yang jelas.

Disarankan bagi pejabat yang akan mengikuti jejak pemerintahan DKI jakarta untuk melakukan lelang jabatan di wilayahnya masing-masing untuk dapat mempelajari apa kelebihan dan kekurangan yang ada dan bisa menutupi dengan merubah cara kerja, butuh keseriusan dan keinginan kuat untuk berusaha mendapat orang yang tepat untuk jabatan yang tepat pula.

\section{DAFTAR PUSTAKA}

C.S.T. Kancil dan Chistine S.T. Kancil, Perbandingan Hukum Administrasi Negara, Rineka Cipta, Jakarta, 2000

Elidar Sari, Hukum Administrasi Negara, Biena Edukasi, Lhokseumawe, 2013

Kamus Hukum, Citra Umbara, Bandung, Cet Ke-5, 2008

Philippus M. Hadjon, dkk, Pengantar Hukum Administrasi Indonesia, UGM Press, Cet.Ke-5, 1997, Yogyakarta

Prajudi Atmosudirjo, Pengantar Administrasi Negara, Ghalia Indonesia, Jakarta, 1982

Rozali Abdullah, Hukum Kepegawaian, Penerbit CV. Rajawali Jakarta, 1986

Utrecht, Pengantar Hukum Administrasi Negara, Penerbit, Balai Buku Ichtiar, Jakarta, 1964

W. F. Prins, dalam R. Kosim Adisapoetra, Pengantar Ilmu Hukum Administrasi Negara, Pradnya Paramita, Jakarta, 1987

Warsito, Pemilihan Kepala Daerah, Jurnal Dialogue, JIAKP, Vol. 2, No. 3, September 2005 